\title{
BIMBINGAN TEKNIS MANAJEMEN PENINGKATAN PENJUALAN MELALUI E-COMMERCE KEPADA IKM/UMKM KOPERASI PATIH DI KELURAHAN CEMPAKA PUTIH KECAMATAN CIPUTAT KOTA TANGERANG SELATAN PROVINSI BANTEN
}

\author{
${ }^{1}$ Yayan Sudaryana, ${ }^{2}$ Masno Marjohan, ${ }^{3}$ Khayatun Nufus, ${ }^{4}$ Jeni Andriani, \\ ${ }^{5}$ Maswarni \\ Dosen Magister Manajemen Universitas Pamulang \\ Email : ${ }^{1}$ yayansudaryana@yahoo.com
}

\begin{abstract}
ABSTRAK
Dalam persaingan usaha, peningkatan penjualan bagi setiap pelaku usaha dengan transaksi perdagangan, baik perdagangan konvensional maupun perdagangan melalui online atau e-commerce (perdagangan elektronik) sangat penting karena harus terus mengikui perkembangan zaman. Koperasi Patih di Kelurahan Cempaka Putih Kecamatan Ciputat Kota Tangerang Selatan memiliki anggota koperasi kurang lebih 180 IKM/UMKM dengan berbagai kegiatan usaha baik sebagai produsen barang dan jasa maupun sebagai pedagang barang dan jasa, yang pada umumnya kegiatan penjualan produk barang dan jasa dilakukan melalui offline dan beberapa IKM/UMKM telah melakukan kegiatan penjualan melalui online/e-commerce baik kepada pelanggan di dalam negeri maupun luar negeri (ekspor).

Metode pelaksanaan adalah dengan memberikan bimbingan teknis, berupa penyuluhan dan pelatihan tentang ketentuan penjualan ke luar negeri (ekspor) melalui e-commerce, terkait dengan ketentuan barang ekspor, cara penyerahan, cara pembayaran, prosedur, jenis dan cara pengisian dokumen ekspor,

Hasil kegiatan ini adalah anggota Koperasi Patih Sejahtera Mandiri mendapatkan pemahaman mengenai peningkatan penjualan melalui e-commerce (perdagangan elektronik) secara aturan dan praktek pelaksanaan di lapangan.
\end{abstract}

\section{Kata Kunci : Manajemen, Penjualan, E-Commerce, Koperasi}

\section{PENDAHULUAN}

Di era globalisasi ini dengan perkembangan teknologi yang begitu pesat, persaingan di dunia bisnis menjadi semakin ketat. Persaingan adalah inti dari kesuksesan atau kegagalan perusahaan. Terdapat dua sisi yang ditimbulkan oleh persaingan, yaitu sisi kesuksesan karena mendorong perusahaan-perusahaan untuk lebih dinamis dan bersaing dalam menghasilkan produk serta memberikan layanan terbaik bagi pasarnya, sehingga persaingan dianggapnya sebagai peluang yang memotivasi. Sedangkan sisi lainnya adalah kegagalan karena akan memperlemah perusahaan-perusahaan yang bersifat statis, takut akan persaingan dan tidak mampu menghasilkan produk-produk yang berkualitas, sehingga persaingan merupakan ancaman bagi perusahaannya. 
Berdasarkan hasil survey pendahuluan berupa wawancara, observasi, serta Fokus Group Diskusi (FGD) dengan Lurah Cempaka Putih Ciputat Tangerang Selatan beserta staf dan Ketua Koperasi Patih, di mana Koperasi memiliki anggota kurang lebih $180 \mathrm{IKM} / \mathrm{UMKM}$ dengan berbagai bidang kegiatan usaha dan bahkan beberapa dari IKM/UMKM anggota Koperasi Patih tersebut telah melakukan transaksi penjualan melalui E-Commerce baik dalam rangka penjualan di dalam negeri maupun ke luar negeri (ekspor). Adapun permasalahan yang di hadapi IKM/UMKM Koperasi Patih Sejahtera Mandiri sebagai berikut:

1. Peranan koperasi masih belum dimanfaatkan secara optimal oleh seluruh anggota. Menurut UU No. 25 Tahun 1992, Koperasi adalah badan usaha yang beranggotakan orang-orang atau badan hokum koperasi, dengan melandaskan kegiatannya berdasarkan prinsip koperasi sekaligus sebagai gerakan ekonomi rakyat yang berdasar atas azas kekeluargaan.

2. Kurangnya pemahaman penjualan melalui e-commerce terutama penjualan ke luar negeri (ekspor). Berdasarkan Peraturan Menteri Perdagangan No. 13 tahun 2012 tentang Ketentuan Umum dibidang Ekspor, bahwa barang ekspor dikelompokkan kedalam 3 kelompok barang yaitu barang bebas ekspornya, barang dibatasi ekspornya dan barang dilarang ekspornya.

Berdasarkan fenomena tersebut, maka diadakan Bimbingan Teknis Manajemen Peningkatan Penjualan Melalui E-Commerce Kepada IKM/UMKM Koperasi Patih Sejahtera Mandiri di Kelurahan Cempaka Putih Kecamatan Ciputat Kota Tangerang Selatan Provinsi Banten.

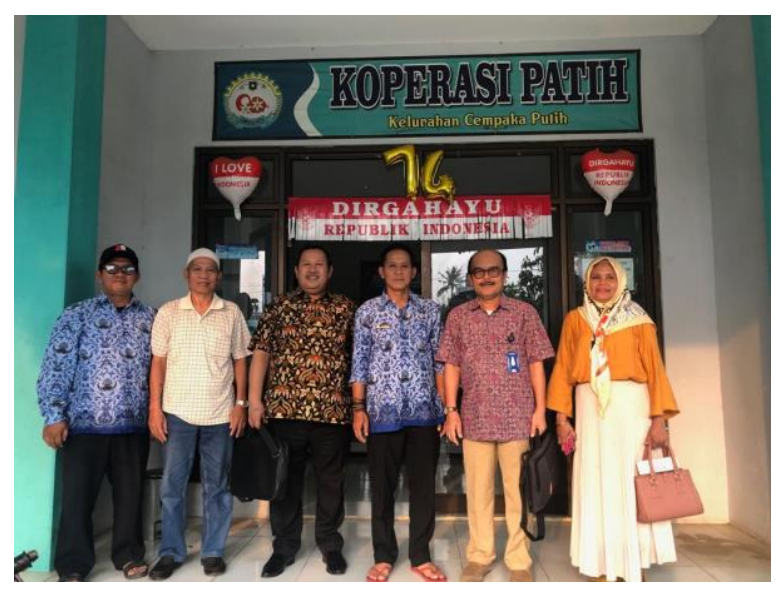

Gambar 1. Foto Besama Pengurus Koperasi Patih Sejahtera Mandiri

\section{METODE PELAKSANAAN KEGIATAN}

Metode pelaksanaan adalah dengan memberikan bimbingan teknis, berupa penyuluhan dan pelatihan tentang ketentuan penjualan ke luar negeri (ekspor) melalui e-commerce, terkait dengan ketentuan barang ekspor, cara penyerahan, cara pembayaran, prosedur, jenis dan cara pengisian dokumen ekspor, yang digambarkan dalam bagan sebagai berikut : 


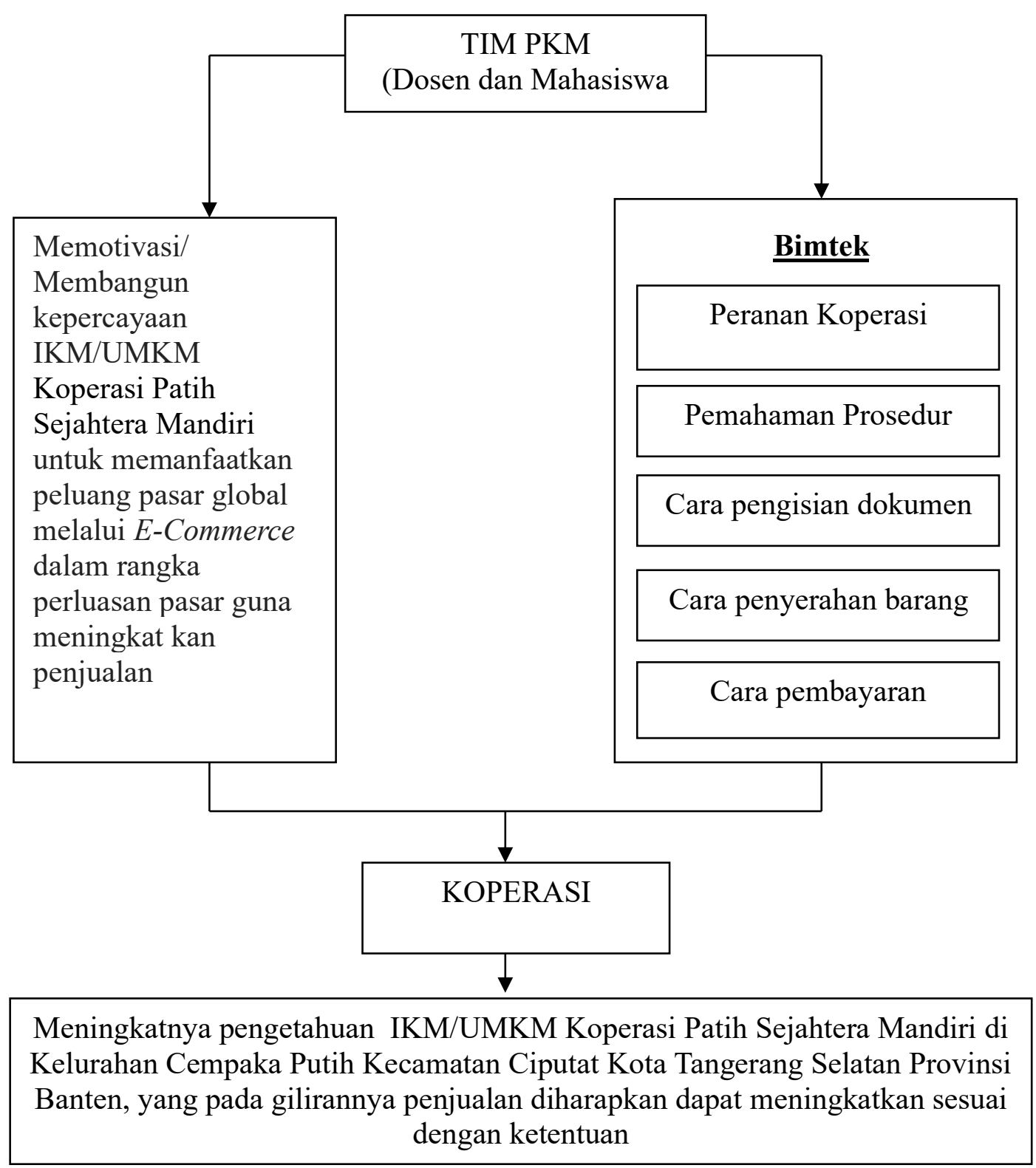

Gambar 2. Alur Kegiatan PKM

Kegiatan diadakan di di Gedung Pertemuan Kantor Kelurahan Cempaka Putih Kecamatan Ciputat Tangerang Selatan, Banten. Waktu pelaksanaan mulai tanggal 22 sampai dengan 23 Oktober 2019. 


\section{HASIL DAN PEMBAHASAN}

Hasil dari kegiatan pelaksanaan bimbingan teknis sebagai berikut :

1. Terkait lembaga, di mana Koperasi masih belum dimanfaatkan secara optimal oleh seluruh anggota. Dalam hal ini sebagai solusinnya maka kepada IKM/UMKM Koperasi Patih di berikan pemahaman tentang tujuan dan manfaat serta peranan koperasi sesuai UU No. 25 Tahun 1992, Koperasi adalah badan usaha yang beranggotakan orang-orang atau badan hukum koperasi, dengan melandaskan kegiatannya berdasarkan prinsip koperasi sekaligus sebagai gerakan ekonomi rakyat yang berdasar atas azas kekeluargaan.

2. Dalam hal kurangnya pemahaman penjualan melalui e-commerce terutama penjualan ke luar negeri (ekspor). Sebagai solusinnya maka kepada IKM/UMKM Koperasi Patih, di berikan pemahaman tentang ketentuan penjualan ke luar negeri (ekspor) melalui e-commerce, terkait dengan ketentuan barang ekspor, cara penyerahan, cara pembayaran, prosedur, jenis dan cara pengisian dokumen ekspor

Pelaksanaan kegiatan Pengabdian Kepada Masyarakat berjalan dengan lancar dan mendapat sambutan hangat baik dari Lurah Cempaka Putih kecamatan Ciputat beserta staf, Ketua Koperasi maupun peserta IKM/UMKM sebagai anggota Koperasi Patih dan bahkan diminta oleh peserta untuk dilanjutkan kegiatan bimbingan ini terutama praktek cara pengisian dokumen ekspor.

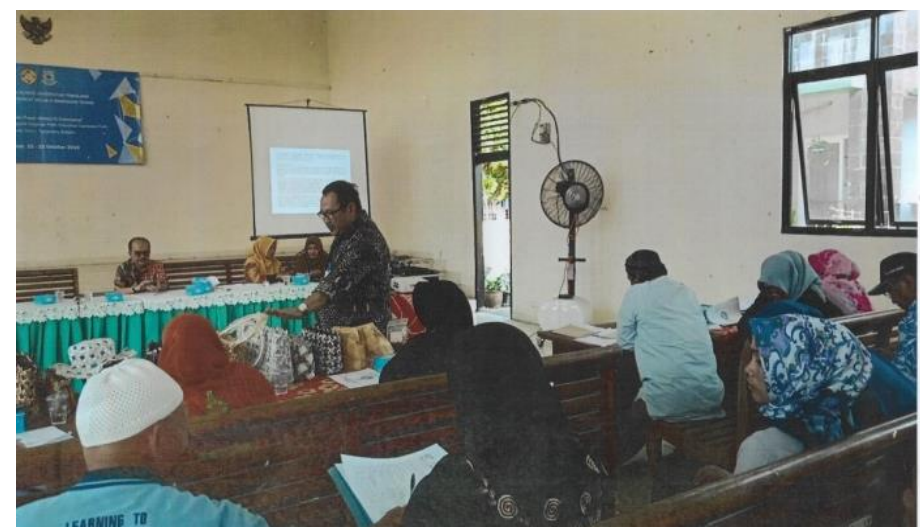

Gambar 3. Sosialisasi dengan Koperasi Patih

\section{KESIMPULAN DAN SARAN}

Hasil kegiatan ini adalah anggota Koperasi Patih sebagai pelaku IKM/UMKM mendapatkan pemahaman dan pembelajaran langsung tentang ketentuan penjualan ke luar negeri (ekspor) melalui e-commerce, terkait dengan ketentuan barang ekspor, cara penyerahan, cara pembayaran, prosedur, jenis dan cara pengisian dokumen ekspor. 
Untuk selanjutnya, perlu dilakukan bimbingan teknik terutama terkait dengan materi praktek cara pengisian dokumen ekspor.

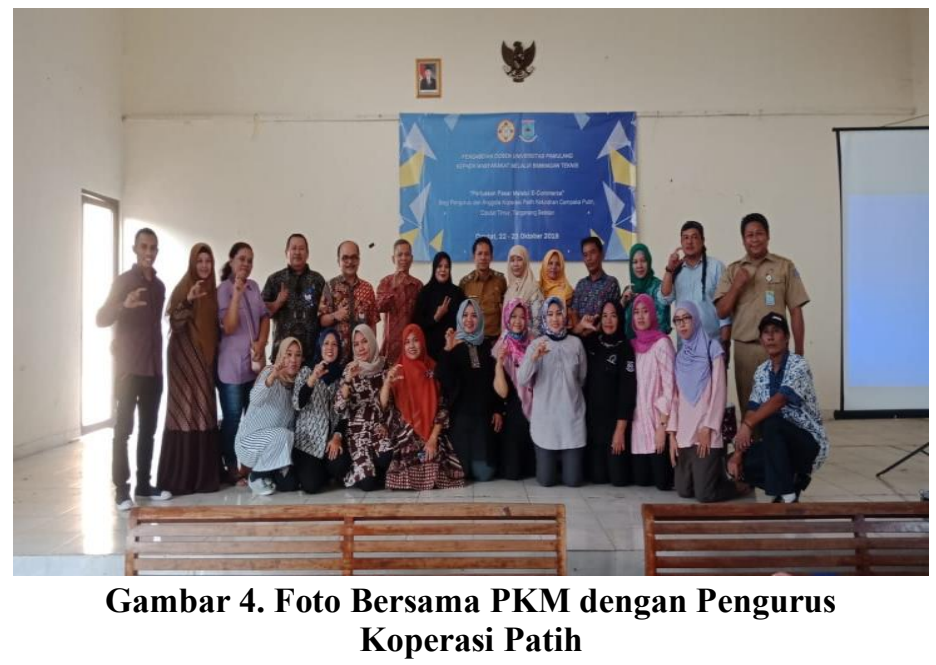

\section{DAFTAR PUSTAKA}

A Sudarsono, D Sunarsi. (2020). Pengaruh Kualitas Pelayanan Dan Varian Produk Terhadap Keputusan Pembelian Pada Laboratorium Klinik Kimia FarmaBintaro. Value: Jurnal Manajemen dan Akuntansi 15 (1), 16-26

Badan Pusat Statistik (BPS), tahun 2018

D Sunarsi. (2014). Pengaruh Gaya Kepemimpinan, Motivasi dan Disiplin Kerja Terhadap Kinerja Pendidik. Universitas Pamulang

D Sunarsi. (2014). Pengaruh Gaya Kepemimpinan, Motivasi dan Disiplin Kerja Terhadap Kinerja Pendidik. Universitas Pamulang

Donni J. Priansa, 2014, Manajemen, Jakarta: PT. Gramedia Pustaka Utama.

Gumilar, I., Sunarsi, D. (2020). Comparison of financial performance in banking with high car and low car (Study of banks approved in the kompas 100 index for the period 2013-2017). International Journal of Psychosocial Rehabilitation. Volume 24 - Issue 7

Jony Wong, dalam Nitisemito 1998, Manajemen Pemasaran, Jakarta Ghali Indonesia

Maddinsyah, A., Sunarsi, D., Hermawati, R., Pranoto. (2020). Analysis of location selection effect on the user decision that influcence the success of the service business of micro, small and medium enterprise (MSME) in bandung timur region. International Journal of Advanced Science and Technology. Vol. 29 No. 06

Peraturan Menteri Perdagangan No. 13 tahun 2012 tentang Ketentuan Umum di bidang Ekspor,

Purwanti, P., Sarwani, S., \& Sunarsi, D. (2020). Pengaruh Inovasi Produk Dan Brand Awareness Terhadap Keputusan Pembelian Konsumen Pada Pt. Unilever Indonesia. Inovasi, 7(1), 24-31. 
Sarwani, S. (2018). Hubungan Antara Perhatian Ibu-Ibu Dalam Menonton Iklan Gizi Di Televisi Dengan Kualitas Perawatan Gizi Di Kecamatan Banjarmasin Selatan Kota Banjarmasin. Metacommunication: Journal of Communication Studies, 2(2).

Sarwani, S. (2019). Pengaruh Kinerja Polri Dan Pelayanan Terhadap Kepuasan Masyarakat Pada Sim Satlantas Polres Tanggamus. Jurnal Simplex, 2(2).

Sunarsi, D., \& Asmalah, L. (2018). Pelatihan Manajemen Pengembangan Diri Bagi Penerima Beasiswa RZIS UGM Dan Dompet Shalahuddin Jogjakarta. Jurnal Pengabdian Dharma Laksana, 1(1), 51-60.

Sunarsi, D., \& Erlangga, A. (2020). The Effect of Leadership Style and Work Environment on the Performance of Stationary Pump Operators in the Water Resources Office of West Jakarta City Administration. International Journal of Advances in Social and Economics, 2(3).

Sunarsi, D., Kustini, E., Lutfi, A. M., Fauzi, R. D., \& Noryani, N. (2019). Penyuluhan Wirausaha Home Industry Untuk Meningkatkan Ekonomi Keluarga Dengan Daur Ulang Barang Bekas. BAKTIMAS: Jurnal Pengabdian pada Masyarakat, 1(4), 188-193.

Sunarsi, D., Kusjono, G., \& Nuryana, I. (2019). Pelatihan Manajemen Penguasaan Kelas Dan Pembuatan Bahan Ajar Bagi Tenaga Pengajar Sukarela Taman Belajar Kreatif Mekarsari. Jurnal Pengabdian Dharma Laksana, 2(1), 41-44.

Susanto, S., Sarwani, S., \& Afandi, S. (2018). Analisis Kinerja Keuangan Untuk Mengetahui Tingkat Kesehatan, Pertumbuhan Dan Prospek Usaha Pada Unit Usaha Koperasi (Studi Kasus Koperasi Awak Pesawat Garuda Indonesia di Tangerang). INOVASI, 1(1).

UU No. 25 Tahun 1992 tentang Koperasi

UU no. 7 tahun 2014 tentang Perdagangan,

UU No. 8 Tahun 1999 tentang Perlindungan Konsumen

UU No.11 Tahun 2008 tentang Informasi dan Transaksi Elektronik (ITE) sebagaimana telah diubah oleh UU No. 19 Tahun 2016 tentang Perubahan atas UU No. 11 Tahun 2008 tentang Informasi dan Transaksi Elektronik (ITE) 